\title{
Pengembangan Bahan Ajar Berbasis History Mapping Pada Materi Sejarah Perkembangan Kota Palembang
}

\author{
Muhammad Reza Pahlevi*, Adhitya Rol Asmi, Y Yunani \\ Universitas Sriwijaya \\ *Corresponding author`s e-mail: mrpahlevi@fkip.unsri.ac.id
}

\begin{abstract}
The research Development of History Mapping-Based Teaching Materials on the material of the history of the development of Palembang City. The formulation of the research problem is how the physical model and the effectiveness of history mapping-based teaching materials in learning the history of the development of Palembang City. As for the purpose of this research is to obtain a prototype and effectiveness of history mapping based teaching materials. This study uses the ADDIE research model where the validity of the material with indicators of suitability and accuracy of the material gets a score of 3.06 with a fairly valid category. The validity of language with indicators of information clarity, conformity with Indonesian language rules, effective and efficient use of language, and legability is 4.4 in the very valid category. The validity of the media with indicators of image quality, text accuracy, color match, video accuracy and information suitabilty is 4.27 in the very valid category. The potential effect of using history mapping based teaching materials at the field trial stage with an average pre-test result of 50.99 in the medium category and an average post test of 56.13 in the moderate category. There was an increase of $5.14 \%$ and the N-Gain value of 0.10 was included in the low category. This shows that history mapping based teaching materials on the historical material for the development of Palembang City have a validity value and an impact on effectiveness in the form of increasing learning outcomes after using materials of history mapping. This research provides empirical evidence that digital teaching materials can increase student enthusiasm and activity which also has effect on improving learning outcomes so it needs for the development of more varied digital products in the learning process.
\end{abstract}

Keywords: teaching materials; history mapping; Palembang

Abstrak: Penelitian pengembangan bahan ajar berbasis history mapping pada materi sejarah perkembangan Kota Palembang. Masalah penelitian bagaimana model fisikal dan efektifitas bahan ajar berbasis history mapping dalam pembelajaran sejarah perkembangan Kota Palembang. Tujuan penelitian mendapatkan prototype dan efektifitas bahan ajar berbasis history mapping. Penelitian menggunakan model ADDIE yang kevalidan materi dengan indikator kesesuaian dan keakuratan materi mendapat nilai sebesar 3,06 dalam kategori cukup valid. Kevalidan bahasa dengan indikator kejelasan informasi, kesesuaian dengan kaidah bahasa Indonesia, penggunaan bahasa secara efektif dan efesien, dan keterbacaan sebesar 4,4 dalam kategori sangat valid. Adapun kevalidan media dengan indikator kualitas gambar, ketepatan teks, kesesuaian warna, ketepatan video, dan kesesuaian informasi sebesar 4,27 dalam kategori sangat valid. Efek potensial penggunaan bahan ajar berbasis history mapping pada tahap uji coba lapangan dengan hasil rata-rata pre test yaitu 50,99 dengan kategori sedang dan rata-rata post test yaitu 56,13 dengan kategori sedang. Terjadi peningkatan sebesar 5,14\% dan nilai N-Gain 0,10 termasuk dalam kategori rendah. Hal ini menunjukan bahan ajar berbasis history mapping pada materi sejarah perkembangan Kota Palembang memiliki nilai kevalidan dan dampak efektivitas berupa peningkatan hasil belajar dalam pembelajaran materi sejarah perkembangan Kota Palembang setelah menggunakan bahan ajar history mapping. Penelitian ini memberikan bukti empiris bahwa bahan ajar digital berupa history mapping dapat meningkatkan antusiasme dan keaktifan mahasiswa yang turut berefek pada peningkatan hasil belajar sehingga perlu adanya pengembangan produk digital yang lebih variatif untuk diterapkan dalam proses pembelajaran.

Kata kunci: bahan ajar; history mapping; Palembang 


\section{Pendahuluan}

Pendidikan adalah sebuah cara yang digunakan untuk mengembangkan kemampuan atau potensi mahasiswa melalui proses pembelajaran menuju perubahan perilaku ke arah yang diharapkan (Fonda, A., dan Sumargiyani, 2018: 110). Pada posisi ini, pendidik memiliki peran yang sangat penting dalam proses pembelajaran. Untuk itu, diperlukan berbagai kompetensi agar proses pembelajaran dapat berjalan dengan baik. Di era digital yang berlandaskan teknologi dan informasi saat ini, pendidik dituntut untuk kreatif, inovatif, dan dapat mengupayakan pembelajaran yang menarik agar memudahkan mahasiswa dalam menerima materi pembelajaran. Salah satu upaya yang dapat dilakukan untuk memudahkan mahasiswa dalam menerima materi adalah dengan menyediakan bahan ajar. Bahan ajar merupakan segala bentuk bahan yang dapat digunakan untuk membantu pelaksanaan pembelajaran. Bahan ajar sendiri dapat dikembangkan dengan menggunakan teknologi agar lebih menarik minat dan memudahkan mahasiswa dalam menerima materi pelajaran.

Salah satu bentuk difusi pembelajaran sejarah dengan teknologi adalah digital history. Cohen et al, 2008: 454 dalam (Sabharwal, 2015: 51) mengatakan bahwa digital history adalah pendekatan yang digunakan untuk merepresentasikan masa lalu yang bekerja dengan teknologi informasi dan komunikasi melalui komputer, jaringan internet, dan sistem perangkat lunak. Sementara itu, Lee (2002: 503) mengatakan bahwa digital history merupakan konstruksi baru yang menggambarkan proses pembelajaran bagi sejarawan/pendidik sejarah dan peserta didik untuk menggunakan alat teknologi dalam mengembangkan keterampilan dan pengetahuan konten dalam disiplin sejarah. Dalam posisi ini, pembelajaran sejarah dimungkinkan untuk adaptif terhadap kehadiran teknologi, sekaligus menjadi alternatif solusi dalam proses pembelajaran di kelas.

Kota Palembang sebagai kota tertua di Indonesia memiliki catatan sejarah yang panjang. Oleh sebab itu, pembelajaran sejarah dengan tema tersebut cenderung sulit untuk dipahami oleh mahasiswa secara utuh. Melalui penelitian ini, peristiwa-peristiwa yang mengisi sejarah panjang Kota Palembang dapat disajikan dengan konsep kronologis sejarah dengan berbasis history mapping. Selain untuk memudahkan pemahaman mahasiswa dalam menerima materi, pembelajaran sejarah dengan menggunakan history mapping juga merupakan salah satu upaya agar proses pembelajaran menjadi menarik dan sesuai dengan jiwa zamannya. History mapping merupakan salah satu bentuk media pembelajaran yang dikembangkan sendiri oleh tim peneliti. Media pembelajaran menurut Munir (2008: 138) merupakan penghubung atau pengantar pesan belajar dari sumber pesan atau pendidik 
kepada penerima pesan atau mahasiswa sehingga terjadi proses interaksi belajar mengajar. Bahan ajar yang dikemas dengan menggunakan media dapat membuat pembelajaran menjadi lebih menarik. Bahan ajar berbasis history mapping ini mengombinasikan berbagai software dalam pembuatan bahan ajar yang akan menjelaskan tentang periodisasi sejarah Kota Palembang yang dilengkapi dengan peta perkembangan kota dengan penambahan warna dan gerak. Selain berfungsi untuk meningkatkan motivasi belajar, bahan ajar yang menggunakan peta dan gambar gerak lainnya dapat membantu peserta didik dalam memahami dan mengingat sejarah dengan lebih baik (Revels, 2013; Sadjati, 2012).

Berdasarkan pada hal-hal yang dikemukakan di atas, maka yang menjadi permasalahan dalam penelitian ini adalah: (1) Bagaimana model fisikal pengembangan bahan ajar berbasis history mapping pada materi sejarah perkembangan Kota Palembang mata kuliah Sejarah Lokal Sumatera Selatan? (2) Bagaimana efektifitas pengembangan bahan ajar berbasis history mapping pada materi sejarah perkembangan Kota Palembang mata kuliah Sejarah Lokal Sumatera Selatan?. Penelitian dengan tema yang sama namun dengan fokus yang berbeda pernah dilakukan oleh Muhammad Istiqlal yang berjudul "Pengembangan Multimedia Interaktif dalam Pembelajaran Matematika". Penelitian ini berhasil mengembangkan multimedia interaktif matematika yang mempunyai kualitas sangat baik dan dapat digunakan sebagai bagian dari strategi belajar mandiri untuk meningkatkan minat belajar siswa (Istiqlal, 2017: 53). Penelitian lain juga dilakukan oleh Sri Rezeki yang berjudul "Pemanfaatan Adobe Flash CS6 berbasis Problem Based Learning pada Materi Fungsi Komposisi dan Fungsi Invers" yang menghasilkan multimedia interaktif yang dapat meningkatkan motivasi, minat pemahaman konsep, dan aktivitas peserta didik terhadap pembelajaran matematika (Rezeki, 2018). Penelitian lainnya juga ditulis oleh Aidil Afriansyah yang berjudul "Rancangan Bangun Media Pembelajaran Coreldraw berbasis Multimedia". Penelitian ini menghasilkan media pembelajaran dengan menggunakan desain grafis Coreldraw berbasis multimedia yang lebih menarik dan lebih mudah dipahami karena materi video dapat diulang tanpa menyesuaikan waktu (Afriansyah, 2018).

Apabila menelaah penelitian terdahulu di atas, maka penggunaan teknologi dalam menunjang proses pembelajaran terbukti layak untuk digunakan. Namun demikian penelitian-penelitian yang terlebih dahulu dikemukakan di atas hanya menggunakan satu software, yakni Coreldraw ataupun Adobe Flash. Oleh sebab itu penelitian ini mencoba membuat bahan ajar yang memanfaatkan beberapa software seperti Coreldraw, Adobe Premiere, dan Movie Maker agar tampilannya lebih menarik dan interaktif. Dalam pembuatan history mapping ini, pengumpulan data peta menggunakan sumber-sumber buku maupun internet direkonstruksikan kembali sesuai dengan materi sejarah perkembangan 
Kota Palembang dari masa Hindu-Buddha hingga masa Indonesia Mutakhir. History mapping dapat menghasilkan peta yang dapat dijadikan sebuah platform sekaligus menjadikan produk yang baik setelah melalui proses tertentu (Delano-Smith, C., Kain, R. J., \& Wood, 2000; Earley-Spadoni, 2017). Adapun dalam penelitian ini, penggunaan history mapping dibutuhkan dalam materi sejarah perkembangan Kota Palembang agar dapat menyajikan sajian materi yang kronologis dengan bantuan peta yang didesain dengan beragam aplikasi pendukung sehingga materi tersaji dengan lebih menarik. Tujuan penelitian ini untuk mendapatkan prototype dan efektifitas pengembangan bahan ajar berbasis history mapping materi sejarah perkembangan Kota Palembang.

\section{Metode}

Penelitian Penelitian ini menggunakan model ADDIE Analysis (Analisis), Design (Desain), Development (Pengembangan), Implementation (Implementasi), dan Evaluation atau Evaluasi (Arkün, S., \& Akkoyunlu, 2008: 4). Model ADDIE merupakan model yang digunakan untuk menghasilkan produk pembelajaran yang efektif dan efesien berupa bahan ajar yang menggunakan media dan teknologi. Penelitian dengan menggunakan model ini kemudian disesuaikan dengan produk yang akan dikembangkan yaitu bahan ajar berbasis history mapping materi sejarah perkembangan Kota Palembang. Setelah disederhanakan atau disesuaikan, berikut adalah tahapan-tahapan dalam implementasinya, yang terdiri dari lima langkah. Pertama, tahap analisis. Langkah ini adalah proses deskripsi dari apa yang akan diajarkan dan langkah awal dari pembentukan langkah selanjutnya.

Pada langkah ini, peneliti menentukan kebutuhan mahasiswa dalam hal pengetahuan, keterampilan dan perilaku, yang saat ini dimiliki oleh mahasiswa, serta hasil yang akan diharapkan dari mahasiswa tersebut (Branch, 2009). Pada tahap analisis, peneliti membagikan angket dan melakukan wawancara dengan beberapa mahasiswa untuk mengetahui produk yang dibutuhkan mahasiswa dalam pembelajaran berdasarkan kebutuhan dan karakteristik mahasiswa. Kedua, tahap desain. Tahapan ini menentukan bagaimana proses pembelajaran yang telah didapat dari tahap analisis untuk dipelajari lebih lanjut. Tahapan ini penting untuk mematangkan perencanaan agar bahan ajar yang dihasilkan baik dan tepat sasaran. Pada tahapan ini juga peneliti mulai membuat rancangan awal materi pembelajaran yang akan dimuat dalam bahan ajar beserta rancangan susunan bahan ajar dalam bentuk flowchart. Pada tahap desain, peneliti juga mempersiapkan alat atau aplikasi yang akan digunakan dalam pembuatan produk. Ketiga, tahap pengembangan. Pada tahap ini, semua komponen yang berhubungan dengan bahan ajar akan dikonversi menjadi multimedia. Tahap ini merupakan proses memproduksi bahan ajar dan semua alat yang akan 
digunakan selama instruksi beserta segala jenis bahan pendukungnya. Pada tahap ini dibutuhkan perangkat laptop yang telah ter-install aplikasi Coreldraw, Adobe Premiere, dan Movie Maker. Pada tahapan ini pula dibuat instrumen angket, soal, dan alat penilaian evaluasi yang akan digunakan peneliti. Pada tahap ini juga peneliti melakukan validasi dengan ahli. Keempat, tahap implementasi. Tahap ini merupakan proses mengukur efektivitas untuk memeriksa sejauh mana bahan ajar berbasis history mapping yang telah diujicobakan pada peserta didik.

Pada tahap ini peneliti menggunakan evaluasi formatif. Kelima, tahap evaluasi yaitu melaksanakan one to one learner dan small group untuk merevisi bahan ajar yang digunakan dan melaksanakan penilaian melalui angket serta melakukan revisi jika ada kekurangan. Pada angket terdapat kolom kritik dan saran, sehingga mahasiswa dapat memberikan masukan untuk bahan ajar. Kemudian tahapan selanjutnya, yaitu field test yang merupakan tahapan uji coba yang berkaitan dengan tahapan implementasi. Sebelum melakukan tahapan implementasi peneliti akan melakukan pre test dan post test untuk menentukan efektivitas bahan ajar. Bagian akhir masing-masing tahapan evaluasi dilakukan untuk memastikan bahwa proses tersebut dilakukan dengan cara yang lebih baik di akhir setiap evaluasi.

\section{Hasil Dan Pembahasan}

Kegiatan Hasil dari tahapan metode ADDIE yang telah dilakukan peneliti kemudian divalidasi oleh ahli. Penilaian kevalidan bahan ajar sendiri akan layak digunakan untuk uji coba apabila mendapat skor rata-rata valid. Berikut merupakan hasil data validasi yang telah dilakukan pada Tabel 1.

Tabel 1. Rekapitulasi Validasi 3 Ahli

\begin{tabular}{ccccc}
\hline $\begin{array}{c}\text { Validasi } \\
\text { Materi }\end{array}$ & $\begin{array}{c}\text { Validasi } \\
\text { Bahasa }\end{array}$ & $\begin{array}{c}\text { Validasi } \\
\text { Media }\end{array}$ & $\begin{array}{c}\text { Rata-Rata } \\
\text { Skor } \\
\text { Perolehan }\end{array}$ & Kriteria \\
3,06 & 4,4 & 4,27 & 3,91 & Valid \\
\hline Berdasarkan & Tabel 1 dapat & diketahui kevalidan & secara keseluruhan sebelum
\end{tabular}

dilakukannya uji coba. Peneliti melakukan tiga validasi, yaitu validasi materi, validasi media, dan validasi bahasa dengan para ahli. Validasi materi dengan indikator kesesuaian dan keakuratan materi divalidasi oleh Dr. Retno Purwanti, M.Hum dengan hasil 3,06 yang berarti cukup valid. Validasi bahasa dengan indikator kejelasan informasi, kesesuaian dengan kaidah bahasa Indonesia, penggunaan bahasa secara efektif dan efesien, dan keterbacaan divalidasi oleh Yenni Lidyawati, S.Pd., M.Pd dengan hasil 4,4 yang berarti sangat valid. Validasi media dengan indikator kualitas gambar, ketepatan teks, kesesuaian warna, ketepatan video, dan kesesuaian informasi mendapat hasil 4,27 yang divalidasi oleh Andy Hary Kusuma, M.Pd dalam kategori sangat valid, dengan kesimpulan bahwa bahan ajar berbasis history mapping 
valid. Dari hasil validasi tersebut menunjukkan perlu adanya revisi terhadap bahan ajar history mapping terutama pada materi yang disajikan. Oleh sebab itu, peneliti melakukan revisi terhadap bahan ajar agar layak diujicobakan ke tahap selanjutnya.

\section{Deskripsi Tingkat Pemahaman dan Keaktifan Mahasiswa terhadap Proses Pembelajaran}

Uji coba bahan ajar berbasis history mapping dilakukan pada mahasiswa Semester 3 Program Studi Pendidikan Sejarah Universitas Sriwijaya dengan jumlah 71 orang. Kegiatan Pre test dilakukan pada saat awal sebelum dilakukannya pembelajaran dan uji coba yang merupakan langkah untuk mengukur kemampuan awal mahasiswa dalam mengetahui informasi mengenai sejarah perkembangan Kota Palembang, sedangkan post test dilakukan untuk mengukur tingkat pemahaman mahasiswa terhadap materi sejarah perkembangan Kota Palembang setelah dilakukannya uji coba bahan ajar berbasis history mapping. Hasil pre test dan post test yang dilakukan oleh peneliti dapat dilihat pada Tabel 2 berikut.

\section{Tabel 2. Rekapitulasi Nilai Pre test dan Post test}

\begin{tabular}{ccccc}
\hline & & Perolehan Nilai & \\
$\mathbf{N}$ & Pre test & Kategori & Post test & Kategori \\
71 & 50,99 & Sedang & 56,13 & Sedang \\
\hline
\end{tabular}

Tabel di atas yang menunjukkan nilai rata-rata yang dicapai oleh mahasiswa pada saat tes awal (pre test) sebesar 50,99 dengan kategori sedang. Sementara itu pada hasil tes akhir (post test), mahasiswa pada uji coba lapangan dengan menggunakan bahan ajar berbasis history mapping materi sejarah perkembangan Kota Palembang mendapatkan nilai rata-rata sebesar 56,13 dengan kategori sedang yang berarti mengalami peningkatan sebesar 5,14\%. Tabel tersebut menunjukkan bahwa pada saat pre test, mahasiswa masih memiliki pengetahuan yang terbatas terkait dengan materi yang disajikan dalam bahan ajar, namun terdapat pula mahasiswa yang telah memiliki pengetahuan awal yang cukup baik. Berdasarkan hasil pre test dan post test yang telah dilakukan dengan menggunakan bahan ajar, mahasiswa mengalami peningkatan nilai. Peningkatan nilai ini terjadi dikarenakan pada saat proses pembelajaran berlangsung, mahasiswa memberi atensi yang baik saat mendengarkan penyampaian materi yang menggunakan bahan ajar history mapping.

Hasil data perhitungan $\mathrm{N}$-gain berdasarkan hasil pre test dan post test didapat $\mathrm{N}$ gain dengan nilai 0,10 yang dapat disimpulkan indeks $\mathrm{N}$-gain termasuk ke dalam kategori rendah. Bahan ajar berbasis history mapping memiliki pengaruh terhadap pemahaman mahasiswa. Hal ini berarti bahan ajar berbasis history mapping materi sejarah perkembangan Kota Palembang layak untuk digunakan sebagai bahan ajar dalam pembelajaran sejarah 
perkembangan Kota Palembang. Tabel 3 menunjukkan nilai keaktifan mahasiswa dalam proses uji coba yang dilakukan.

\section{Tabel 3. Rekapitulasi Nilai Keaktifan Mahasiswa}

\begin{tabular}{cccccccc}
\hline & \multicolumn{5}{c}{ Perolehan Nilai } \\
$\mathbf{N}$ & Indikator & & Jumlah Nilai & Rata-Rata & Kategori \\
71 & 5 & & \multicolumn{3}{c}{342,59} & 68,52 & Aktif \\
\hline Berdasarkan & hasil & tabel & di & atas, ada & lima indikator & berupa
\end{tabular}

keseriusan/memperhatikan, mencatat materi, mendengarkan dengan aktif, mengelola informasi, dan mengerjakan soal memiliki jumlah nilai dari lima indikator yakni 342,59\% dan menghasilkan nilai rata-rata $68,52 \%$ yang berarti mahasiswa aktif ketika peneliti melakukan uji coba. Peningkatan nilai keaktifan disebabkan karena sebelum penelitian mahasiswa belum pernah menggunakan bahan ajar history mapping. Hal baru berupa penggunaan bahan ajar history mapping membuat mahasiswa tertarik dan lebih banyak berinteraksi dalam pembelajaran. Mahasiswa merespon dan memahami bahan ajar yang diujicobakan, sehingga bahan ajar berbasis history mapping materi sejarah perkembangan Kota Palembang mampu menciptakan suasana belajar yang aktif.

\section{Deskripsi Kemenarikan Bahan Ajar Berbasis History Mapping}

Peneliti melakukan validasi produk bahan ajar kepada ahli yang memahami mengenai perancangan dan pengembangan bahan ajar berbasis history mapping materi sejarah perkembangan Kota Palembang. Tabel 4 merupakan data perbaikan dan masukan yang diberikan oleh ahli validasi.

\section{Tabel 4. Daftar Perbaikan dan Masukan Ahli}

\begin{tabular}{rrl}
\hline No. & \multicolumn{1}{c}{ Validator } & \multicolumn{1}{c}{ Revisi } \\
\hline 1. Ahli Materi & $\begin{array}{l}\text { Perlu ditambahkan informasi terbaru dan mengacu kepada data } \\
\text { termutakhir serta perbaikan nama penguasa pada masa } \\
\text { Kedatuan Sriwijaya. }\end{array}$ \\
2. Ahli Bahasa & Perlu perbaikan ejaan, tata kalimat, dan jenis tulisan \\
3. Ahli Media & - \\
\hline
\end{tabular}

Data perbaikan dan masukan dari ahli pada tabel di atas menunjukkan perbaikan yang perlu dilakukan dalam pengembangan bahan ajar berbasis history mapping materi sejarah perkembangan Kota Palembang. Peneliti melakukan perbaikan sesuai dengan seluruh masukan ahli untuk mendapatkan hasil produk yang valid. Hasil dari kemenarikan bahan ajar dilakukan pada tahapan data lapangan dan diperoleh dari rekapitulasi skor respon menggunakan angket yang dapat dilihat pada Tabel 5. 
Tabel 5. Rekapitulasi Kemenarikan Produk

\begin{tabular}{|c|c|c|c|c|c|}
\hline \multirow{2}{*}{$\begin{array}{c}\text { Uji } \\
\text { perorangan } \\
92\end{array}$} & \multirow{2}{*}{$\begin{array}{c}\begin{array}{c}\text { Uji Kelompok } \\
\text { Kecil }\end{array} \\
88,4\end{array}$} & \multirow{2}{*}{$\begin{array}{c}\text { Rerata Skor } \\
\text { Perolehan } \\
90,2\end{array}$} & \multirow{2}{*}{$\begin{array}{l}\text { Kriteria } \\
\text { Sangat } \\
\text { Menarik }\end{array}$} & \multicolumn{2}{|c|}{ Kesimpulan } \\
\hline & & & & $\begin{array}{l}\text { Memenuhi } \\
\text { menarik } \\
\text { produk } \\
\text { digunakan }\end{array}$ & $\begin{array}{r}\text { sangat } \\
\text { sehingga } \\
\text { layak }\end{array}$ \\
\hline
\end{tabular}

Berdasarkan pada tabel di atas diketahui bahwa keseluruhan hasil analisis produk memperoleh persentase sebesar 90,2. Selanjutnya hasil dari persentase tersebut dapat ditafsirkan dan diputuskan bahwa produk bahan ajar berbasis history mapping materi sejarah perkembangan Kota Palembang yang dikembangkan, masuk pada kriteria sangat menarik untuk digunakan dalam pembelajaran. Beberapa saran dan komentar dari uji kemenarikan dari tahap one to one learners dengan tiga responden mahasiswa Program Studi Pendidikan Sejarah Semester Tiga antara lain yaitu: (1) perpaduan kontras (warna) dan tulisan sangat baik; (2) materi yang disampaikan sangat menarik dan layak digunakan, karena materi yang disampaikan lebih mudah dipahami dan juga tidak membosankan dengan tambahan audio dan gambar yang sangat menarik dan kreatif; serta (3) produk sudah baik dan menarik namun akan lebih baik bila ditambahkan gambar-gambar dari narasi yang disampaikan.

Saran dan komentar dari tahap small group, dengan sepuluh mahasiswa Semester Tiga Program Studi Pendidikan Sejarah Universitas Sriwijaya antara lain yaitu: (1) materi yang disampaikan sangat mudah dimengerti serta gambar mapping yang ditampilkan sangat jelas, sehingga mempermudah mahasiswa untuk mempelajarinya; (2) materi yang dijelaskan sudah sesuai dengan urutannya dan mudah dipahami; (3) jenis huruf yang ditampilkan sebaiknya jenis huruf yang tebal agar memudahkan dalam membaca keterangan di video.

\section{Produk Bahan Ajar Berbasis History Mapping}

Produk akhir dari proses pengembangan ini berupa bahan ajar berbasis history mapping untuk pembelajaran sejarah di Mata Kuliah Sejarah Lokal Sumatera Selatan pada mahasiswa Pendidikan Sejarah Semester 3. Produk history mapping menekankan pada kekuatan peta sebagai narator dalam memberikan sajian informasi sejarah secara keseluruhan. Hal ini juga didukung oleh pendapat Haines, (2017: 62) yang menyatakan bahwa ketika peta digunakan untuk menarasikan sejarah, peta tersebut dapat mempersempit pemikiran pembaca tentang masa lalu, menggambarkan dalam bentuk dialektis berdasarkan gambaran sendiri dan memproyeksikan sebuah "gambar hampa dan melemahkan" menggambarkan pemikiran yang lain yang membuat pembaca lebih berfikir 
sederhana mengenai kejadian sejarah. Selain itu, Kashibadze, V. F., Nasonova, O. G., \& Nasonov (2013: 3) juga mengatakan bahwa penggunaan aplikasi video pemetaan bisa memperlihatkan banyak pola berbeda yang tersembunyi, dimana setiap pola memiliki kandungan sejarah tertentu. Bahan ajar berbasis history mapping ini merupakan bahan ajar yang dihasilkan melalui proses pengeditan video menggunakan berbagai program aplikasi untuk menghasilkan video yang berkualitas dengan ukuran durasi 18:09 menit dan memiliki ukuran file 1,3 GB dengan materi sejarah lokal Sumatera Selatan yaitu sejarah perkembangan Kota Palembang.

Bahan ajar berbasis history mapping materi sejarah perkembangan Kota Palembang dapat digunakan secara berulang-ulang dimana pun dan kapan pun sehingga mahasiswa dapat lebih baik lagi dalam memahami materi. Pengulangan dalam mendengarkan materi melalui bahan ajar berbasis history mapping materi sejarah perkembangan Kota Palembang yang mengkombinasikan audio dan visual, dapat melatih daya ingat dan pemahaman secara kronologis sehingga materi yang disampaikan dalam bahan ajar dapat dipahami dengan baik.
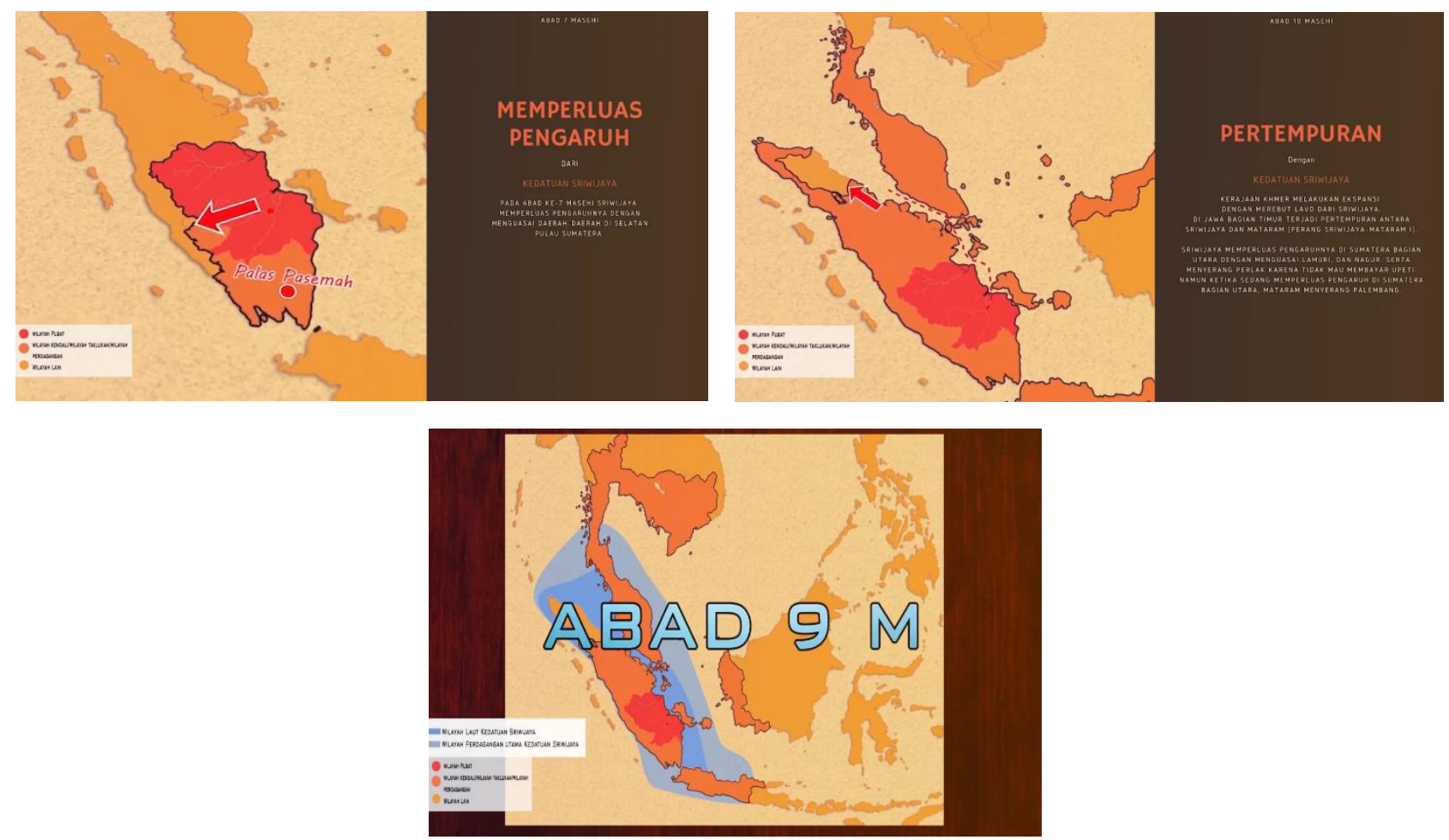

Gambar 1. Tampilan Bahan Ajar

(Dokumentasi Pribadi, 2020)

Gambar 1 di atas menunjukkan beberapa tampilan bahan ajar history mapping. Dari gambar tersebut menunjukkan bahwa bahan ajar disajikan dengan warna beserta simbolsimbol dan pada sisi kanan peta terdapat deskripsi untuk menarasikan suatu peristiwa 
sejarah yang akan dijelaskan. Bahan ajar history mapping ini sendiri menampilkan peristiwa secara kronologis dengan mencantumkan peristiwa-peristiwa penting yang terjadi di setiap rentang waktunya. Secara keseluruhan, bahan ajar berbasis history mapping materi sejarah perkembangan Kota Palembang ini layak dan efektif untuk digunakan dalam proses pembelajaran. Hal ini dapat dilihat berdasarkan evaluasi yang dilakukan oleh beberapa ahli, yaitu ahli materi 3,06, ahli bahasa 4,4, dan ahli media 4,27 dengan perolehan rata-rata 3,91 yang termasuk kategori valid untuk dilakukan pada tahap selanjutnya. Selain itu, bahan ajar juga diuji cobakan pada kelompok perorangan dan kelompok kecil, serta uji coba lapangan dengan nilai pre test dan post test yang mengalami peningkatan nilai setelah penggunaan bahan ajar.

Bahan ajar history mapping memiliki kekuatan pada peta yang menarik sebagai narator dalam memberikan sajian informasi sejarah secara keseluruhan. Bahan ajar berbasis history mapping dapat memberikan kemudahan dalam mempelajari sejarah dengan cakupan materi yang panjang dan kompleks. Selain itu, bahan ajar berbasis history mapping ini dapat digunakan berulang kali dan fleksibel. Berdasarkan dari data perhitungan $N$-gain yang telah dihasilkan berdasarkan hasil pretest dan posttest, didapat $\mathrm{N}$-gain dengan nilai 0,10 yang dapat disimpulkan jika indeks $\mathrm{N}$-gain $\leq 0,30$ maka indeks $\mathrm{N}$-gain termasuk kedalam kategori rendah sehingga bahan ajar berbasis history mapping memiliki pengaruh terhadap pemahaman materi mahasiswa. Sementara itu, ujicoba perorangan dilakukan dengan tiga orang dan uji coba kelompok kecil dilakukan dengan 10 orang. Kegiatan uji coba perorangan dan uji coba kelompok kecil dilakukan untuk mengetahui pendapat mahasiswa terhadap bahan ajar. Adapun perolehan persentase uji coba perorangan berada di angka 92.

Uji coba kelompok kecil memiliki hasil 88,4 sehingga menghasilkan rata-rata 90,2 yang berarti sangat baik. Beberapa respon dan saran mahasiswa yang menyatakan bahwa bahan ajar berbasis history mapping mudah untuk digunakan dan sangat membantu mahasiswa dalam proses pembelajaran. Berdasarkan hal tersebut, maka bahan ajar berbasis history mapping dapat meningkatkan efektivitas pembelajaran dan menunjang proses pembelajaran sejarah, khususnya materi sejarah perkembangan Kota Palembang. Peningkatan efektivitas disebabkan karena bahan ajar history mapping dikemas dengan menarik sehingga dapat meningkatkan antusiasme dan keaktifan mahasiswa. Hal tersebut berimplikasi pada pemahaman mahasiswa sehingga terjadi peningkatan hasil belajar setelah dilaksanakan proses pembelajaran dengan bahan ajar history mapping. 


\section{Kesimpulan}

Berdasarkan analisis temuan yang dipaparkan di atas, maka dapat ditarik kesimpulan bahwa bahan ajar berbasis history mapping efektif untuk digunakan dan mampu menunjang kebutuhan pembelajaran sejarah di era digital saat ini. Kelebihan bahan ajar berbasis history mapping yang telah dikembangkan ini adalah dapat memberikan kemudahan dalam mempelajari sejarah dengan cakupan materi yang panjang dan kompleks. Selain itu, bahan ajar berbasis history mapping ini dapat digunakan kapan pun dan dimana pun oleh mahasiwa, serta dapat digunakan secara berulang kali. Kekurangan dari bahan ajar berbasis history mapping yakni dibutuhkan program aplikasi yang mendukung dalam pembuatan bahan ajar dan pembuatannya memerlukan waktu yang tidak sedikit serta biaya yang cukup besar. Penelitian ini memberikan bukti empiris bahwa bahan ajar digital berupa history mapping dapat meningkatkan antusiasme dan keaktifan mahasiswa yang turut berimplikasi pada peningkatan hasil belajar.

Pembelajaran di era digital saat ini menuntut para pendidik untuk mengadaptifkan diri sesuai dengan jiwa zaman yang ada. Untuk itu, para pendidik disarankan untuk terus mengembangkan materi ajar dengan memanfaatkan teknologi yang terus berkembang. Pengembangan bahan ajar berbasis history mapping ini merupakan salah satu dari banyak alternatif pembelajaran berbasis teknologi yang dapat dilakukan. Oleh sebab itu, peneliti berharap para pendidik dapat terus berinovasi dan selalu tanggap terhadap perubahan zaman. Urgensi teknologi digital di dalam proses pembelajaran di masa kini dan masa depan sudah menjadi sebuah keharusan. Penelitian ini diharapkan dapat memberikan kontribusi dalam pengembangan bahan ajar digital yang lebih variatif dan interaktif di masa mendatang.

\section{Daftar Pustaka}

Afriansyah, A. 2018. Rancang Bangun Media Pembelajaran Coreldraw Berbasis Multimedia. Jurnal TIPS: Jurnal Teknologi Informasi Dan Komputer Politeknik Sekayu, 8(1), 3845.

Arkün, S., \& Akkoyunlu, B. 2008. A Study on the development process of a multimedia learning environment according to the ADDIE model and students' opinions of the multimedia learning environment. Interactive Educational Multimedia: IEM, 17, 119.

Branch, R. 2009. Instructional Design: The ADDIE Approach. Springer.

Delano-Smith, C., Kain, R. J., \& Wood, A. A. 2000. English maps: A History. Cartographica, 37(3), 63. https://doi.org/https://doi.org/10.1016/B978-0-08-102295-5.10518-9

Earley-Spadoni, T. 2017. Spatial History, deep mapping and digital storytelling: archaeology's future imagined through an engagement with the Digital Humanities. Journal of Archaeological Science, 84, https://doi.org/http://dx.doi.org/10.1016/j.jas.2017.05.003

Fonda, A., dan Sumargiyani, S. 2018. The developing math electronic modul with Scientifiec approach using kvisoft flipbook maker pro for XI grade of senior high school students. Infinity Journal, 7(2), 109-122. 
Haines, E. 2017. Mapping out History: A Cartographic View of The Twentieth Century. Journal of Historical Geography, 55, 60-68. https://doi.org/http://dx.doi.org/10.1016/j.jhg.2016.12.004

Istiqlal, M. 2017. Pengembangan Multimedia Interaktif Dalam Pembelajaran Matematika. JIPMat, 2(1).

Kashibadze, V. F., Nasonova, O. G., \& Nasonov, D. S. 2013. Reconstructions of human history by mapping dental markers in living Eurasian populations. Quaternary International, 284, 3-6. https://doi.org/doi:10.1016/j.quaint.2011.07.022

Lee, J. K. 2002. Digital history in the history/social studies classroom. The History Teacher, 35(4), 503-518.

Munir. 2008. Kurikulum Berbasis Teknologi Informasi dan Komunikasi. Alfabet.

Revels, C. S. 2013. Seeking Refuge: Birds and Landscapes of the Pacific Flyway. Journal of Historical Geography, 42 , https://doi.org/http://dx.doi.org/10.1016/j.jhg.2013.07.015

Rezeki, S. 2018. Pemanfaatan Adobe Flash Cs6 Berbasis Problem Based Learning Pada Materi Fungsi Komposisi Dan Fungsi Invers. Jurnal Pendidikan Tambusai, 2(4), 856-864.

Sabharwal, A. 2015. Digital history, archives, and curating digital cultural heritage. Digital Curation in the Digital Humanities, 2013, 49-67. https://doi.org/10.1016/b978-008-100143-1.00003-9

Sadjati, I. M. 2012. Hakikat Bahan Ajar. Universitas Terbuka. 